\title{
Питання психології
}

УДК 159.923 .2

DOI: $10.33099 / 2617-6858-20-55-2-28-36$

Березовська Л. І. кандидат психологічних наук, доџент, Національний університет «Львівська політехніка». https://orcid.org/0000-0002-5972-7883

\section{ВПЛИВ СОЦІАЛЬНИХ МЕРЕЖ НА ПСИХОЛОГІЧНЕ БЛАГОПОЛУЧЧЯ ОСОБИСТОСТІ}

У статті представлено результати теоретичного та емпіричного дослідження впливу соиіальних мереж на психологічне благополуччя особистості. Визначено більш психологічно благополучними тих, хто перебуває у соџіальних мережсах не значний час. Виявлено взаємозв 'язки між тривалістю перебування у соціальних мережах, психологічним благополуччям, задоволеністю життям, емочійними бар' єрами у спілкуванні, само ставленням, комунікативними здібностями.

Ключові слова: сочіальні мережі; психологічне благополуччя; задоволеність життям; емоційні бар'єри у спілкуванні; само ставлення; комунікативні; організаторські здібності.

Актуальність дослідження.

Зараз соціальні мережі стали невід'ємною частиною життя значної кількості людей. 3 кожним місяцем все більше людей у світі, що користуються Інтернетом $є$ зареєстрованими у соціальних мережах. Так, наприклад, Facebook зараз $є$ тією платформою, на якій 2,603 мільярда людей $\epsilon$ активними користувачами. [6] Статистика свідчить, що зараз в Індії є 280 мільйонів користувачів, в США - 190 мільйонів, Індонезії - 130 мільйонів, Бразилія - 120 мільйонів. Щомісячно дану мережу відвідує близько 3,5 мільярдів відвідувачів.

Згідно 3 опитуванням компанії Research \& Branding Group в Україні найбільш популярними соціальними мережами $\epsilon$ Facebook $(58 \%$ від усіх респондентів), YouTube (41\%), Instagram (28\%), Telegram (14\%). Значно знизився інтерес до таких мереж як Вконтакте (7\%), Одноклассники (6\%) i twitter (5\%), та Linkdn (1\%). [5]

Аналіз останніх досліджень i публікацій

Соціальні мережі - це Інтернетплатформи, які дозволяють людям, що мають схожі інтереси збиратися, обмінюватися інформацією, світлинами, відео.

Соціальна мережа в Інтернеті це інтерактивний багатокористувацький вебсайт, зміст якого наповнюється самими учасниками мережі. Авторство терміну «соціальна мережа» належить англійському соціологу Барнсу. У 1954 році у збірці робіт «Людські стосунки» він його використав для позначення спільноти людей, що об'єднані однаковими інтересами, вподобаннями, або тих, хто має інші причини для безпосереднього спілкування між собою. Перша соціальна мережа (у сучасному розумінні) - Classmates.com була створена Ренді Конрадом в 1995 році.

Вивченням соціальних мереж займались як зарубіжні (А. Войскунський, А. Голдберг, Д. Грінфілд, К. Янг), так і українські вчені (О.Бєлінська, Ю.Данько, С. Акімова, Ю. Бабаєва, А. Жичкина, О. Філатова та ін.). На даний час досліджується роль соціальних мереж у комунікації, соціальній взаємодії, мотивації, розвитку смисложиттєвих орієнтацій, індивідуальних цінностей, особистісного розвитку, пізнавальних процесів, вплив на ціннісні орієнтації, стиль життя, вибір мети i шляхів іiі реалізації та ін.. Значна частина розвідок присвячена негативному впливу віртуального спілкування на особистість, ризиків, що несе спілкування в соціальних мережах, причини виникнення Інтернетзалежності. Значно менше є досліджень, що розкривають роль зазначеного феномену у психологічному благополуччі особистості.

Щодо психологічного благополуччя, то вперше воно було описано Norman M. Bradburn півстоліття назад у монографії «The Structure of Psychological well - being», що була опублікована у США [2]. Тут же було представлено результати дослідження щастя, що були здійснені Norman M. Bradburn ra David Caplovitz.

Психологічне благополуччя тривалий час досліджується в рамках гедоністичного та евдемоністичного підходів [1]. Гедоністичний підхід розробляється 


\section{Питання психології}

переважно в контексті когнітивної i поведінкової психології (А. С. Ватерман, Э. Деси, Д. Каннеман, Р. Райан). Його представники описують благополуччя в основному у термінах задоволеності незадоволеності, що будується на балансі позитивного та негативного. Евдемоністичний підхід розробляється представниками гуманістичної психології [2]. В його рамках психологічне благополуччя розглядається як доброчесне життя, виявлення та реалізація справжнього Я, здатність відповідати на екзистенційні життєві виклики, самоактуалізація й особистісне зростання. Уявлення про психологічне благополуччя відрізняються комплексністю, глибиною змісту.

Психологічне

благополуччя

розглядається позитивне психологічне функціонування особистості [2].

Теоретичні концепції, що орієнтовані на дослідження позитивного психологічного функціонування особистості стали основою багатовимірної моделі психологічного благополуччя К. Ріфф. Дана модель психологічного благополуччя містить: позитивне ставлення до себе i свого минулого життя; наявність цілей і занять, що додають життю сенс; здатність виконувати вимоги повсякденного життя; відчуття безперервного розвитку i самореалізації; відносини 3 іншими, пронизані турботою і довірою; здатність наслідувати власні переконання [2].

Відомими дослідженнями $\epsilon$ ті, що «психологічне благополуччя» розглядають на основі психофізіологічного збереження функцій. Вважають, що генетичні чинники також можуть пояснити індивідуальні відмінності в психологічному благополуччі (Е. Дісі, Р. Райан, К. Фредерік) [2].

А також «психологічне благополуччя» розглядається як цілісне переживання, що виражене в суб'єктивному відчутті щастя, задоволеності собою і власним життям, а також є пов'язаним з базовими людськими цінностями та потребами [2].

Отже, психологічне благополуччя розглядається як позитивне функціонування особистості, як континуум «задоволення - незадоволення»; як збереження психофізіологічних функцій; як цілісне суб'єктивне переживання особистості.
Мета дослідження визначення впливу соціальних мереж на психологічне благополуччя особистості.

Методи дослідження.

Дослідження впливу соціальних мереж на психологічне благополуччя особистості здійснено на основі авторської анкети та інструментальних методик («Шкала психологічного благополуччя» (К. Ріфф) адаптована Л.В. Жуковською и Е.Г. Трошихиною [1]; Індекс життєвої задоволеності (Bernice L. Neugarten c колегами) (адаптація Н. В. Паніної) [7]; «Діагностика емоційних бар'єрів у міжособистісному спілкуванні (за В. Бойко)» [4]; «Тест-опитувальник для визначення самоставлення особистості (В.В. Столін, С.Р. Пантелеєв)» [2] та Оцінка комунікативних i організаторських схильностей (КОЗ) Б.А. Федоришина [4].

У дослідженні взяли участь 126 осіб, вік 18-22 роки, 65 дівчат та 61 хлопець. Опитування проводилося як під час безпосередніх контактів 3 досліджуваними та через соціальну мережу Facebook.

Виклад основного матеріалу.

За авторською анкетою «Соціальні мережі в нашому житті», що містила 17 запитань визначено переваги щодо користування мережами, тривалість часу перебування в мережі, ставлення до соціальних мереж, вплив соціальні мережі на людину, як на особистість. Питання стосувалися щодо друзів, особливостей спілкування, а також щодо впливу соціальних мереж на психологічне благополуччя спілкування.

Опитування показало, що всі респонденти залучені до соціальних мереж. Більшість їх користуються одночасно кількома соціальними мережами. Найбільше їх $є$ зареєстрованими в таких мережах, як Instagram (94\%), Facebook (90\%), ВКонтакте (80\%), Telegram (68\%), Twitter (10\%). Зараз для молоді престижно мати багато підписників в мережі Instagram, автори сторінок хизуються ними, змагаються у цифрах залучених до своїх сторінок, своєї історії, своїх фотографій. Щодо підписок в Instagram, то у $12 \%$ досліджуваних є до 100 підписок, у 30\% від 100 до 200 підписок, у 58\% 200 і більше підписок.

Серед наших опитуваних 56\% проводять в соціальних мережах до 4 годин 


\section{Питання психології}

у день, 44\% досліджуваних більше 4 годин. Соціальні мережі для 60\% досліджуваних $\epsilon$ засобом спілкування, для 20\% можливостями нового знайомства, $10 \%$ джерелом інформації, 10\% - місцем для розваг. Хоча в той же час переважна кількість їх надають перевагу спілкуванню не віртуальному і друзі у них переважно реальні.

Більше половини 3 опитаних вважають, що соціальні мережі впливають на особистість, на здоров'я людини, на стосунки 3 оточуючими, диктують стиль життя, допомагають орієнтуватися при покупці товарів і послуг. А також всі досліджувані зазначили, що соціальні мережі так або інакше впливають на їхнє психологічне благополуччя.
Оскільки у нас сформувалися дві групи залежно від тривалості перебування у соціальних мережах, то подальший аналіз ми здійснили порівнюючи ці групи між собою. До 1 групи ми віднесли тих, хто проводить у соціальних мережах до 4 годин, до 2 групи - тих, хто більше 4 годин.

Насамперед проаналізуємо прояв психологічного благополучч, як позитивного психологічного функціонування особистості, у групах залежно від тривалості перебування у соціальних мережах. Для цього була використано методику «Шкала психологічного благополуччя» (К. Ріфф), що адаптована Л.В.Жуковською и Е. Г. Трошихиною (рис.

1).

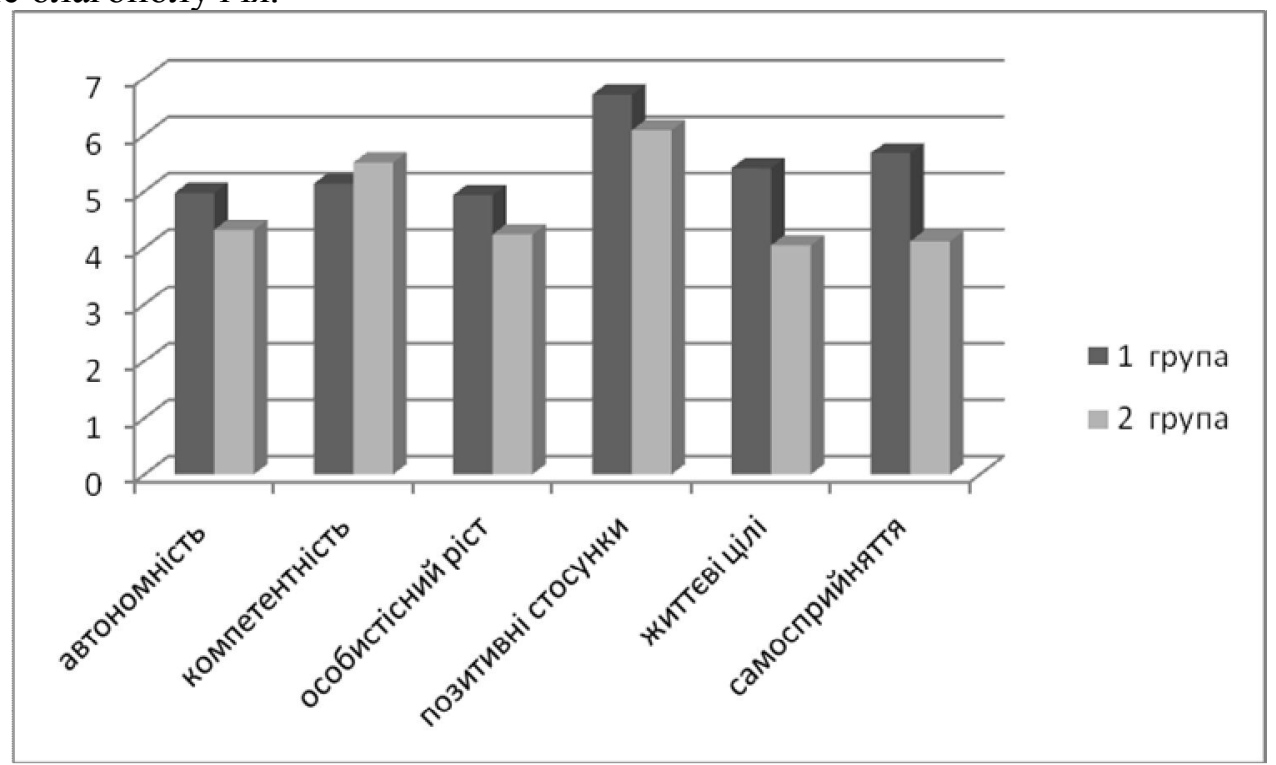

Рис. 1. Психологічне благополуччя.

Примітка: тривалість перебування у соціальних мережах: 1 група - до 4 год., 2 група - більше 4 год.

Досліджувані, що проводять у соціальних мережах до 4 годин, відчувають себе психологічно більш благополучно функціональними, ніж ті, витрачають значно більше часу в Інтернеті. У них на статистичному рівні відмічається відмінність за шкалами «автономність», «життєві цілі» та «самосприйняття» Психологічне благополуччя, позитивне психологічне функціонування в них проявляється в автономії, здатності протистояти соціальному тиску в своїх думках та вчинках, оцінювати себе на основі особистих стандартів; мають мету у своєму житті, позитивно ставляться до себе та свого минулого.
В рамках гедоністичного підходу дослідження психологічне благополуччя описується в основному у термінах задоволеності - незадоволеності, що будується на балансі позитивного та негативного. При цьому задоволення трактується в широкому сенсі - це не лише тілесне задоволення, але і задоволення від досягнення значущої мети, результатів [1]. Про психологічне благополуччя також свідчить і відчуття задоволеності життям, яке ми дослідили за методикою Індекс життєвої задоволеності (Bernice L. Neugarten с колегами) (адаптація Н.В. Паніної) (рис. 2). 


\section{Питання психології}

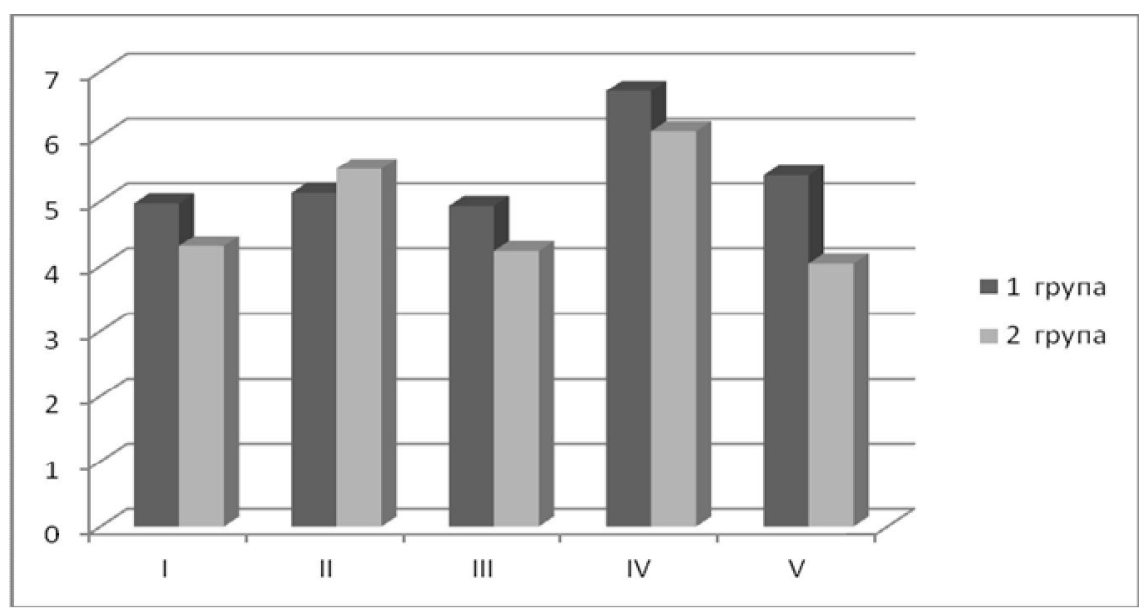

Рис. 2. Життєва задоволеність.

Примітки: 1) шкали: I - інтерес до життя, II - послідовність у досягненні цілей, III - узгодженість між поставленими і досягнутими цілями, IV - позитивна оцінка себе і власних вчинків, V - загальний фон настрою; 2) тривалість перебування в соціальних мережах: 1 група - до 4 год., 2 група - більше 4 год.

Щодо суб'єктивного переживання своєї благополучності, то досліджувані, що проводять у соціальних мережах до 4 годин у день $є$ більш задоволеними, мають вищий інтерес до життя та більш позитивний фон настрою. За шкалами «інтерес до життя» та «загальний фон настрою» відмічаються відмінності на статистично значимому рівні. За всіма шкалами показники вищі у групі досліджуваних, що перебувають у соціальних мережах не більше 4 годин.

Отже, перебування у соціальних мережах, спілкування у віртуальному просторі не робить людину більш психологічно благополучною.

Для людини $\epsilon$ важливим $\epsilon$ міжособистісне спілкування. Якщо ми отримуємо достатньо спілкування в реальному житті, або воно нас не задовольняє, то ми можемо звернутися до віртуального спілкування. Тут ми можемо задовольнити свої нереалізовані потреби у спілкуванні. Через нього ми можемо мати як багато позитивних моментів, так i негативних. Буває, що легше спілкуватися 3 людиною через екран, ніж в реальному житті, в якому є багато емоцій, що або допомагають у процесі міжособистісного спілкування, або заважають нам порозумітися. Оскільки спілкування між людьми (реальне або віртуальне) завжди насичене емоціями, тому доцільним вважаємо описати ті емоційні бар'єри, які заважають у процесі цього спілкування. Їх ми дослідили за методикою діагностики емоційних бар'єрів у міжособистісному спілкуванні (за В.В. Бойко) (рис. 3).

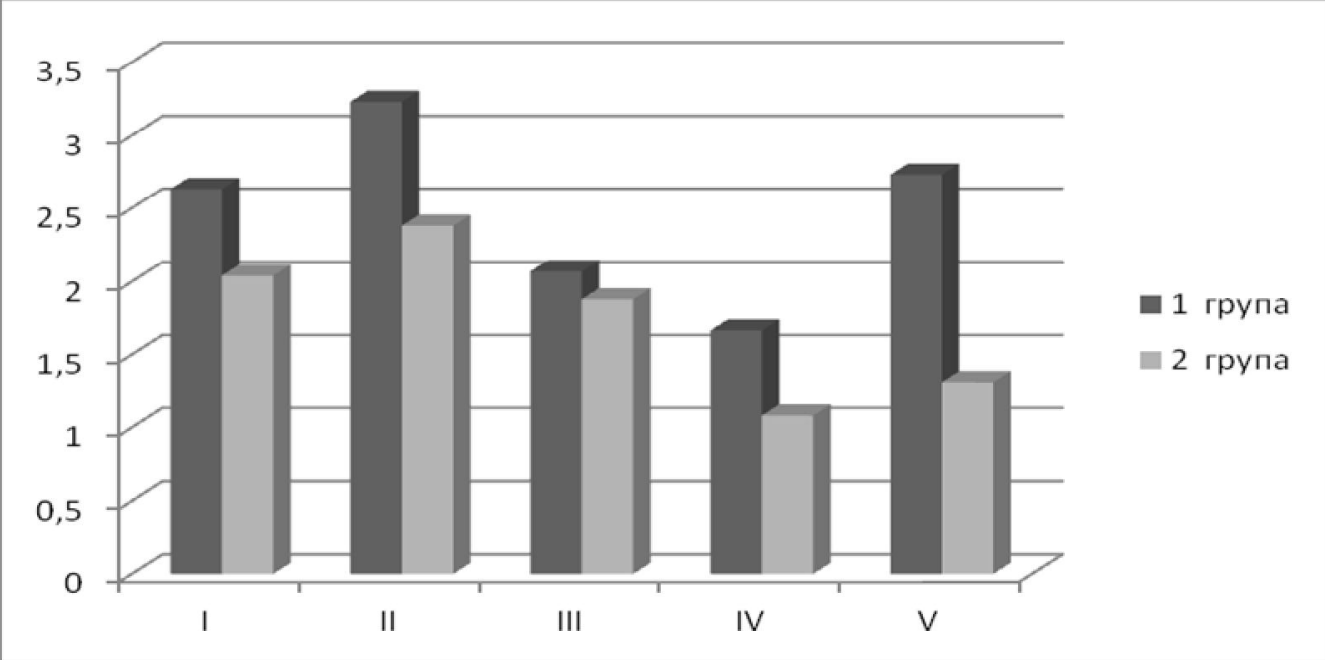

Рис. 3. Емоційні бар'єри у міжособистісному спілкуванні.

Примітки: шкали: I - невміння керувати емоціями, II - неадекватний прояв емоцій, III негнучкість та не виразність емоцій, IV - домінування негативних емоцій, V - небажання зближатися з людьми на емоційній основі. час перебування соціальних мереж: 1 група - до 4 годин, 2 група - більше 4 годин. 


\section{Питання психології}

В результаті ми отримали неочікувані дані. Досліджувані, що складають групу 3 нетривалим часом перебування у соціальних мережах частіше проявляють емоційні бар'єри у спілкуванні. На статистичному рівні визначено відмінності за майже всіма шкалами. У них сильніше проявляється невміння керувати емоціями, неадекватно проявляють емоції, у них домінують негативні емоції та не бажають емоційно зближатися з іншими. Тобто безпосереднє емоційне спілкування 3 людьми визначає їхнє ставлення до інших, це може бути i психологічним захистом. Щодо тих досліджуваних, що складають групу 3 перебуванням у соціальних мережах більше 4 годин, то в них менше емоцій, і вони мабуть менше будують емоційних бар'єрів у процесі міжособистісного спілкування.
Очевидно це пов'язано $з$ тим, інтенсивність спілкування та безпосередне спілкування більш $\epsilon$ насиченим, ніж спілкування у соціальних мережах, де можна приховати свої емоцій.

Отже, група досліджуваних що проводить у соціальних мережах менше 4 годин у день більше демонструє невміння керувати емоціями та неадекватний їх прояв та не бажає емоційно зближатися з людьми.

Відмінності у рівні комунікативних та організаторських здібностей досліджуваних 3 різною тривалістю перебування у соціальних мережах визначено за методикою «Оцінка комунікативних i організаторських схильностей» (КОС) Б.А. Федоришина (рис. $4)$.

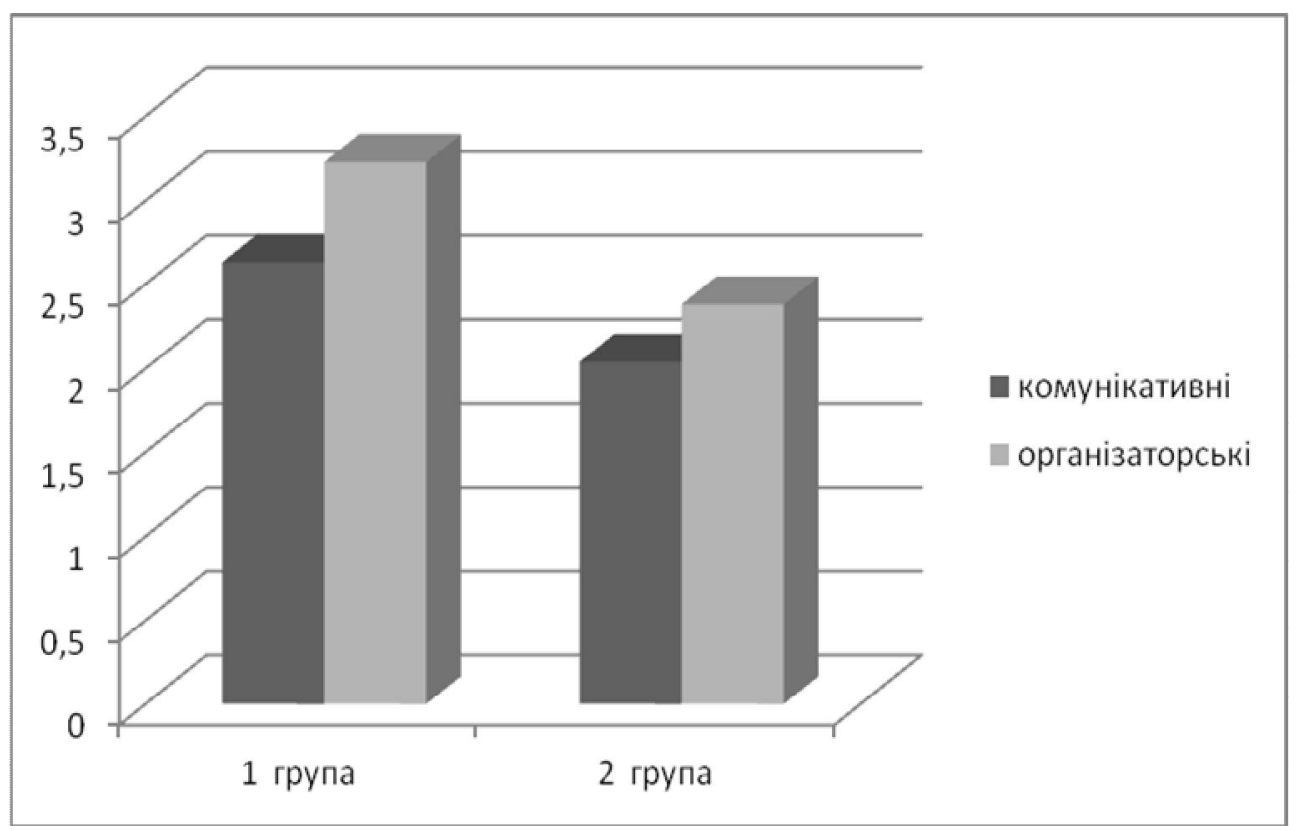

Рис. 4. Комунікативні та організаторські здібності.

Примітка: тривалість перебування в соціальних мережах: 1 група - до 4 год., 2 група - більше 4 год.

Також отримано неочікувані данні. Група, представники якої проводять у соціальних мережах більше 4 годин має вищі показники. А також вона характеризується середнім рівнем прояву організаторських та комунікативних здібностей. Тобто вони більше прагнуть до контактів $з$ людьми, не обмежують коло своїх знайомств, відстоюють свою думку, планують свою роботу, однак потенціал їх схильностей не відрізняється високою стійкістю. Очевидно тому у них так багато підписок та віртуальних друзів, багатьох 3 яких вони і не знають. А також далеко не 3 усіма вони спілкуються активно та систематично.

Отже, спілкування в соціальних мережах приводить до підвищення комунікативних та організаторських здібностей, що може свідчити про бажаний рівень їх в опитаних. I це може впливати на їхнє психологічне благополуччя.

Ставлення до себе досліджуваних ми визначили за методикою самоставлення особистості (В.В. Столін, С.Р. Пантелеєв) (рис. 


\section{Питання психології}

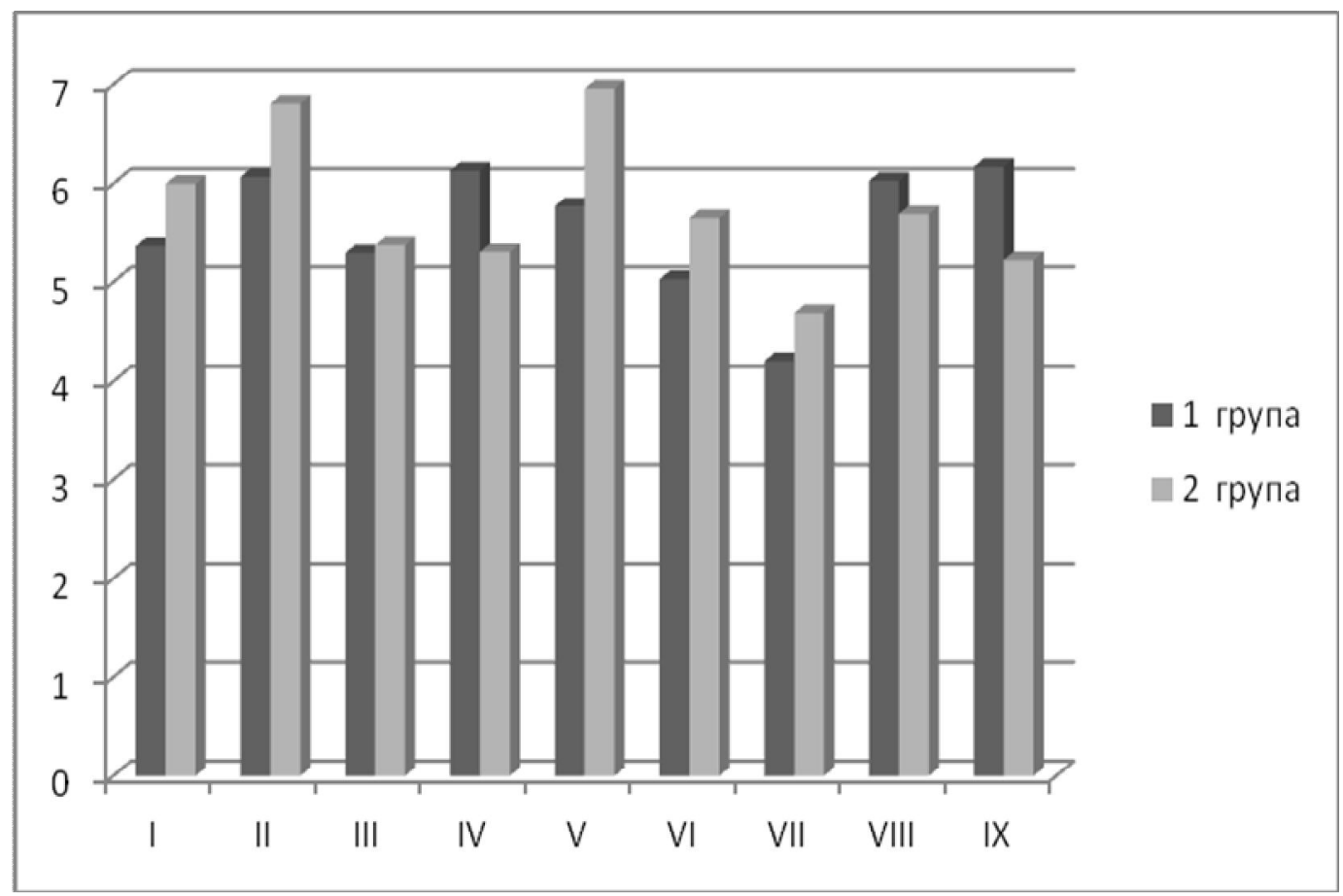

Рис. 5. Самоставлення досліджуваних.

Примітки: шкали: I - відкритість, II - самовпевненість, III - самокерівництво, IV - дзеркальне «Я», V самоцінність, VI - само прийняття, VII - самоприв'язаність, VIII - внутрішня конфліктність, IX самозвинувачення. тривалість перебування в соціальних мережах: 1 група - до 4 год., 2 група - більше 4 год.

Досліджувані, що проводять у Зазначимо, що за 8-ма шкалами соціальних мережах до 4 годин вважають, що вони викликають в інших повагу, симпатію, схвалення та розуміння, здатні до рефлексії, звинувачують себе у своїх промахах та невдачах частіше, ніж ті, хто проводить більше часу у віртуальному спілкуванні. Тобто в групі, що обмежений час проводить у соціальних мережах вищі середні значення за шкалами «дзеркальне Я», «внутрішня конфліктність» та «самозвинувачення». Щодо інших шкал, то за шкалами «відкритість», «самовпевненість», «самоцінність», «само прийняття», «самоприв'язаність» вищим $\epsilon$ у групі досліджуваних, що проводить у соціальних мережах більше 4 годин. Очевидно вони через соціальні мережі отримують віртуальну підтримку, підвищують свою значимість у своїх очах, багато віртуальних друзів легко надають схвалення (через «лайки»), кількість підписок піднімають їх у своїх очах. У соціальних мережах опитувані відчувають себе більш цінними, впевненими, $\epsilon$ відкритими, менше звинувачують себе, ніж в реальному житті та приймають себе (точніше складений образ себе). спостерігаються відмінності на статистичному рівні.

Отже, для групи опитаних, що проводять у соціальних мережах більше 4 годин на день притаманні більш високі показники відкритості, самовпевненості, самоцінності, само прийняття та самоприв'язаності, а також нижчі дзеркального Я, внутрішньої конфліктності та самозвинувачення.

Для визначення взаємозалежностей було застосовано кореляційний аналіз. Його було здійснено за допомогою програмного забезпечення SPSS v.21. Це дало нам змогу проаналізувати особливості взаємовпливу соціальних мереж та психологічне благополуччя через показники різних методик.

Проаналізуємо окремо отримані кореляційні зв'язки для кожної групи досліджуваних. В таблиці 1 представлено взаємозв'язки на рівні менше 0,05 між тривалістю перебування у соціальних мережах та іншими шкалами в групі досліджуваних (група 1), що перебувають у соціальних мережах не більше 4 годин у день. 


\section{Питання психології}

Таблиця 1

Результати кореляційного аналізу групи 1.

\begin{tabular}{|l|l|l|l|}
\hline \multicolumn{1}{|c|}{ Шкала 1 } & \multicolumn{1}{|c|}{ Шкала 2 } & \multicolumn{1}{c|}{$\mathbf{R}$} & \multicolumn{1}{c|}{$\boldsymbol{p}$} \\
\hline тривалість віртуального спілкування & Автономність & 0,300 & 0,015 \\
\hline тривалість віртуального спілкування & Компетентність & 0,388 & 0,001 \\
\hline тривалість віртуального спілкування & Відвертість & 0,433 & 0,000 \\
\hline тривалість віртуального спілкування & Самовпевненість & 0,366 & 0,003 \\
\hline тривалість віртуального спілкування & Дзеркальне «Я» & 0,344 & 0,005 \\
\hline тривалість віртуального спілкування & Негнучкість та невиразність емоцій & 0,592 & 0,000 \\
\hline тривалість віртуального спілкування & Домінування негативних емоцій & 0,304 & 0,014 \\
\hline тривалість віртуального спілкування & Комунікативні здібності & $-0,475$ & 0,000 \\
\hline
\end{tabular}

Отже, у групі, що перебуває в взаємозв'язку. Тобто, зі збільшенням часу соціальних мережах до 4 годин тривалість віртуального спілкування має прямі помірні кореляційні зв'язки 3 такими шкалами психологічного благополуччя, як: автономність та компетентність. Щодо інших показників, то такі шкали самоставлення як: відвертість, самовпевненість та дзеркальне «Я»; емоційних бар'єрів у спілкуванні як: негнучкість, невиразність емоцій, домінування негативних емоцій також мають прямі помірні та помірні взаємозв'язки 3 тривалістю перебування у соціальних мережах. В той же час комунікативні здібності перебувають у зворотному перебування у соціальних мережах підвищуються показники автономності, компетентності, впевненості у собі, підвищується негнучкість, невиразність емоцій, домінування негативних емоцій (вищі показники - менше вміння керувати своїми емоціями), знижуються комунікативні здібності, і навпаки.

В таблиці 2 представлено взаємозв'язки на рівні менше 0,05 між тривалістю перебування у соціальних мережах та іншими шкалами в групі досліджуваних, що перебувають у соціальних мережах більше 4 годин у день.

Таблиця 2

Результати кореляційного аналізу групи 2.

\begin{tabular}{|c|l|l|c|}
\hline Шкала 1 & \multicolumn{1}{|c|}{ Шкала 2 } & \multicolumn{1}{c|}{$\mathbf{R}$} & \multicolumn{1}{c|}{$\boldsymbol{p}$} \\
\hline тривалість віртуального спілкування & Компетентність & $-0,531$ & 0,000 \\
\hline тривалість віртуального спілкування & Позитивні стосунки & $-0,509$ & 0,000 \\
\hline тривалість віртуального спілкування & Життєві цілі & $-0,339$ & 0,008 \\
\hline тривалість віртуального спілкування & Інтерес до життя & $-0,379$ & 0,003 \\
\hline тривалість віртуального спілкування & Загальний фон настрою & $-0,300$ & 0,025 \\
\hline тривалість віртуального спілкування & Відвертість & $-0,342$ & 0,007 \\
\hline тривалість віртуального спілкування & Самокерівництво & 0,422 & 0,000 \\
\hline тривалість віртуального спілкування & Самоцінність & $-0,610$ & 0,000 \\
\hline тривалість віртуального спілкування & Самоприв’язаність & $-0,358$ & 0,005 \\
\hline тривалість віртуального спілкування & Внутрішній конфлікт & 0,399 & 0,003 \\
\hline тривалість віртуального спілкування & Невміння керувати емоціями & $-0,580$ & 0,000 \\
\hline тривалість віртуального спілкування & Неадекватний прояв емоцій & 0,419 & 0,001 \\
\hline тривалість віртуального спілкування & Домінування негативних емоцій & $-0,416$ & 0,001 \\
\hline тривалість віртуального спілкування & $\begin{array}{l}\text { Небажання зближатися з людьми на } \\
\text { емоційній основі }\end{array}$ & 0,320 & 0,012 \\
\hline
\end{tabular}

Результати кореляційного аналізу групи, що перебуває у соціальних мережах більше 4 годин свідчать, що збільшення тривалості віртуального спілкування знижує показники психологічного благополуччя за шкалами: компетентність, позитивні стосунки, життєві цілі, інтерес до життя, загальний фон настрою (помітні та помірні зворотні кореляційні зв'язки). Щодо само ставлення, то зі збільшенням часу перебування у соціальних мережах знижується відвертість, цінність себе, прив'язаність до себе та підвищується внутрішньо особистісний конфлікт. Зі збільшенням тривалості перебування у соціальних мережах збільшується небажання зближатися 3 людьми на емоційній основі та неадекватний прояв емоцій, в той же час знижується невміння керувати емоціями та домінування негативних емоцій.

Отже, тривалість перебування у соціальних мережах впливає на психологічне благополуччя, само ставлення, емоційні бар'єри у спілкуванні та комунікативні здібності. 


\section{Питання психології}

\section{Висновки та перспективи подальших досліджень.}

1. Феномен «психологічне благополуччя» досліджується в рамках евдемоністичних та гедоністичних теорій; на базі позитивного психологічного функціонування особистості; розглядається 3 точки зору збереження психофізіологічних функцій; як цілісне суб'єктивне переживання особистості.

2. Всі досліджувані залучені до соціальних мереж i більшість їх користуються одночасно кількома соціальними мережами. Найбільше $\epsilon$ зареєстрованими в таких мережах, як Instagram, Facebook, Telegram. Більше половини досліджуваних в Instagram мають 200 і більше підписок Соціальні мережі для більшості досліджуваних $є$ засобом спілкування та можливостями нового знайомства.

3. Досліджувані, що проводять у соціальних мережах до 4 годин, відчувають себе психологічно більш благополучно функціональними, $є$ більш задоволеними, мають вищий інтерес до життя та більш позитивний фон настрою, ніж ті, витрачають значно більше часу в Інтернеті.

4. Досліджувані, що складають групу з нетривалим часом перебування у соціальних мережах частіше проявляють емоційні бар'єри у спілкуванні. В той же час група, представники якої проводять у соціальних мережах більше 4 годин мають вищі показники прояву організаторських та комунікативних здібностей.

5. Досліджувані, що у соціальних мережах проводять обмежений час демонструють більш позитивне само ставлення за шкалами «дзеркальне Я», «внутрішня конфліктність» та «самозвинувачення», а ті, що проводять у соціальних мережах більше 4 годин за шкалами «відкритість», «самовпевненість», «самоцінність», «само прийняття», «самоприв'язаність».

6. У групі, що перебуває у соціальних мережах до 4 годин у день кореляційні зв'язки між тривалістю перебування $\mathrm{y}$ соціальних мережах та параметрами психологічного благополуччя, емоційних бар'єрів у спілкуванні, само ставлення, комунікативних здібностей. У групі, що спілкується у соціальних мережах більше 4 годин кореляційних зв'язків значно більше. Спостерігаються між тривалістю перебування у соціальних мережах та параметрами психологічного благополуччя, життєвої задоволеності, емоційних бар'єрів у спілкуванні, само ставлення.

Перспективи подальшого дослідження вбачаємо у дослідженні структури психологічного благополуччя в осіб, що мають Інтернет-залежність.

\section{Список використаних джерел}

1. Жуковская Л.В., Трошихина Е.Г. Шкала психологического благополучия К. Рифф // Психологический журнал, 2011. Т. 32. № 2. С. 82-93.

2. Індивідуальні ресурси психологічного благополуччя особистості : монографія / за ред. М.Й. Варій, О.А. Ліщинська, Л.І. Березовська, А.В. Олійник, Г.М. Закалик. Львів : Вид-во Львівської політехніки, 2018. 168 с.

3. Практикум із загальної психології / за ред.. Т.І. Пашукової. 2-ге вид., стер. К. : Т-во «Знання», KOO, 2006. - 203 c

4. Українці назвали найпопулярніші соціальні мережі. - https://www.rbc.ua/ukr/news/ukraintsynazvali-samye-populyarnye-sotsialnye-1582734412.html

5. Most popular social networks worldwide as of July 2020, ranked by number of active users https://www.statista.com/statistics/272014/global-social-networks-ranked-by-number-of-users/

6. Neugarten B. L., Havinghuret R. J., Tobin S. S. The Measurement of Life Satisfaction // Journal of Gerontology. 1961. 1. №16. P. 141.

\section{References}

1. Zhukovskaya L.V., Troshikhina Ye.G. Shkala psikhologicheskogo blagopoluchiya [Scale of psychological well-being by K. Riff] // Psikhologicheskiy zhurnal, 2011. T. 32. № 2. S. 82-93. (in Ukrainian).

2. Indyvidualni resursy psykholohichnoho blahopoluchchia osobystosti [Individual resources of psychological well-being of the individual]: monohrafiia / za red. M.I. Varii, O.A. Lishchynska, L.I. Berezovska, A.V. Oliinyk, H.M. Zakalyk. Lviv : Vyd-vo Lvivskoi politekhniky, 2018. 168 s. (in Ukrainian).

3. Praktykum iz zahalnoi psykholohii [Workshop on general psychology] / za red.. T.I. Pashukovoi. 2-he vyd., ster. K. : T-vo «Znannia», KOO, 2006. 203 s (in Ukrainian).

4. Ukraintsi nazvaly naipopuliarnishi sotsialni merezhi [Ukrainians named the most popular social networks]. - https://www.rbc.ua/ukr/news/ukraintsy-nazvali-samye-populyarnye-sotsialnye-1582734412.html 


\section{Питання психології}

5. Most popular social networks worldwide as of July 2020, ranked by number of active users https://www.statista.com/statistics/272014/global-social-networks-ranked-by-number-of-users/

6. Neugarten B. L., Havinghuret R. J., Tobin S. S. The Measurement of Life Satisfaction // Journal of Gerontology. 1961. 1. №16. P. 141.

\section{Резюме}

Березовская Л. И. кандидат психологических наук, дочент,

Национальный университет «Львівська політехніка».

\section{ВОЗДЕЙСТВИЕ СОЦИАЛЬНЫХ СЕТЕЙ НА ПСИХОЛОГИЧЕСКОЕ БЛАГОПОЛУЧИЕ} ЛИЧНОСТИ

В статье представлены результаты теоретического и эмпирического исследования влияния сочиальных сетей та психологическое благополучие личности. Определено более благополучными тех, кто бывает в социальных сетях недлительное время. Выявлено взаимосвязи между временем пребьвания в социальных сетях, психологическим благополучием, удовлетворенностью жизни, эмочиональными барьерами в общении, самоотношением, коммуникативными способностями.

Ключевые слова: сочиальные сети; психологическое благополучне; удовлетворенность жизнью; эмочичональные барьеры в общении; самоотночение; коммуникативные; организаторские способности.

\section{Summary \\ Berezovska L. I. Candidate of Psychological Sciences, THE IMPACT OF SOCIAL NETWORKS ON THE INDIVIDUAL'S PSYCHOLOGICAL Associate Professor Lviv Polytechnic National University \\ WELL-BEING}

The article presents the results of theoretical and empirical research on the impact of social networks on the individual's psychological well-being.

Nowadays, social networks have become an integral part of modern life, and with each passing month more and more Internet users are being registered in various social networks worldwide. In Ukraine, the most popular social networks are Facebook, YouTube, Instagram, Telegram.

The phenomenon of "psychological well-being" has been studied: within the framework of eudemonistic and hedonistic theories; based on the positive psychological functioning of an individual; considered in terms of preservation of psycho-physiological functions; as a holistic subjective experience of an individual.

It is determined that all our respondents are involved in social networks, and most of them use several social networks at the same time. Most are registered in such networks as Instagram, Facebook, Telegram. More than half of Instagram respondents have 200 or more subscriptions. For the majority of respondents, social networks are a means of communication and opportunities for new acquaintances.

Respondents, who spend up to 4 hours on social networks, feel more functional psychologically, are more satisfied, have a higher interest in life, and have a more positive mood than those who spend much more time online.

Respondents from the group with a short stay on social networks are more likely to show emotional barriers to communication. At the same time, the group whose representatives spend more than 4 hours on social networks, has higher rates of organizational and communication skills.

Respondents, who spend limited time on social networks, show a more positive attitude on "looking-glass self", "internal conflict" and "self-blame" scales, and those who spend more than 4 hours on social networks on "openness", "self-confidence", "self-worth", "self-acceptance", "self-attachment" scales.

Correlations between the length of stay in social networks and the parameters of psychological wellbeing, emotional barriers in communication, attitude, communication skills have been determined in the group that is on social networks for up to 4 hours a day. In the group that communicates on social networks for more than 4 hours, there are many more correlations. There are correlations between the length of stay in social networks and the parameters of psychological well-being, life satisfaction, emotional barriers to communication, attitude.

We see prospects for further research in the study of the structure of psychological well-being in people with Internet addiction.

Keywords. Social networks, psychological well-being, emotional barriers to communication, attitude, communication, organizational skills. 